\title{
First assessment of the Malta Leprosy Eradication Project
}

\author{
D L LEIKER \\ Royal Tropical Institute, 63 Mauritskade, 1092 AD Amsterdam, \\ The Netherlands
}

\begin{abstract}
After the first publications on the Malta Leprosy Eradication Project by Freerksen et al., reporting excellent results and absence of serious side-effects of the drug combination used, doubt about the validity of the data presented still remained. In 1978, four years after most patients had been released from treatment, I was assigned by WHO, as a temporary advisor to the Government of Malta, to make an independent assessment of the project.

This paper concentrates on three questions: 1 Is the patient material in Malta suitable for evaluating the efficacy of a treatment regimen? 2 Were the sideeffects as mild as had been reported? 3 Was there any indication of relapses or forthcoming relapses?
\end{abstract}

\section{The patient material}

Most patients had received, prior to the treatment with rifampicin and Isoprodian, prolonged treatment with sulphones. There was also some doubt about the classification of patients. In many patients the disease could have been burned out and then relapse would be unlikely, irrespective of the treatment.

In 1978, in most patients typical symptoms required for classification had subsided, and in many patients it had become difficult or impossible to classify the patients on the basis of clinical symptoms alone. The clinical examination was therefore supplemented by the examination of a skin biopsy and by a lepromin test. Also the clinical records prior to and during the project period were examined. The results of frequent bacteriological examinations of smears (usually every 2-4 months) were available.

On the basis of all these data the patients were classified. There remained no doubt that patients who are classified in this paper as lepromatous, are indeed lepromatous or near-lepromatous. Altogether the status of 86 lepromatous and 46 nonlepromatous patients could be assessed reliably. 
The majority of the patients had received, prior to MDT, prolonged treatment with sulphones and many had been treated with thiacetasone or thiabutosine (Table 1).

However, when MDT was started, a very high proportion of the patients were still bacteriologically positive in smears and/or biopsies. It is of interest that the percentage of bacteriologically positive patients is inversely correlated with the duration of previous treatment. This may be due to decreasing compliance with drug intake. The records showed substantial lack of compliance with drug collection prior to MDT.

Many patients have received low doses of sulphones, often fortnightly sulphone injections. It is therefore probable that many patients harboured sulphone resistant strains of $M$. leprae.

About $50 \%$ of the patients classified as nonlepromatous had shown, prior to the onset of MDT, bacteriologically positive smears and $30 \%$ were still bacteriologically positive at the onset of MDT. This means that a high proportion of the patients who were classified as nonlepromatous were borderline tuberculoid or borderline, and may have been borderline lepromatous. Only a small proportion were polar tuberculoid.

Of the 86 lepromatous patients, 68 were bacteriologically positive at the onset of MDT. After 24 years of MDT, 66 were still positive. Four years after withdrawal of treatment 42 were found to be bacteriologically positive. In 12 other patients who were still positive the BI had decreased measurably after cessation of treatment (Table 2).

\section{Side-effects}

All records were examined. The attendance for drug collection was very regular. During the project period the records were carefully kept. Minor complaints were also recorded. The incidence of side-effects was relatively high. About $25 \%$ of the

Table 1. Treatment-and bacteriological status of lepromatous patients at onset of MDT.

\begin{tabular}{ccc}
\hline $\begin{array}{c}\text { No. years } \\
\text { treated }\end{array}$ & $\begin{array}{c}\text { No. } \\
\text { patients }\end{array}$ & $\begin{array}{c}\text { BI positive at } \\
\text { onset of MDT }\end{array}$ \\
\hline $0-4$ & 17 & $17(100 \%)$ \\
$5-9$ & 13 & $7(54 \%)$ \\
$10-19$ & 28 & $17(61 \%)$ \\
$20+$ & 20 & $15(75 \%)$ \\
\hline
\end{tabular}


Table 2. Bacteriological status of nonlepromatous patients.

\begin{tabular}{lc}
\hline & BI positive \\
\hline Time of diagnosis & $23(50 \%)$ \\
Time of onset of MDT & $14(30 \%)$ \\
Time of termination of MDT & $0(0 \%)$ \\
\hline
\end{tabular}

patients had reported gastrointestinal complaints and $13 \%$ other complaints such as dizziness (Table 3 ).

However, the treatment was not withdrawn for any of these patients and no patient stopped attendance because of these complaints. No evidence of serious liver toxicity of the drug combination was found.

Between the onset of MDT and the time of assessment 22 patients had died. This seems to be a high death rate. However, the fact that the average age of the patients in Malta was high should be taken into account. Attempts were made to trace the cause of death (Table 4).

This was not possible in 8 patients. However, all these patients had died only after having completed the course of MDT. Of the 14 other patients the cause of death was traced. In 13 patients no reason was found for assuming a connection with the chemotherapy of leprosy. In one patient, who died of renal failure, the possibility of a relationship with the chemotherapy could not be excluded.

\section{Relapses}

On clinical examination no evidence of relapse was found. In none of the biopsies was any cellular activity suggesting a relapse, or forthcoming relapse, seen. In no

Table 3. Side-effects of rifampicin-Isoprodian in 196 patients

\begin{tabular}{|c|c|c|}
\hline Gastr & c discomfort, nausea, vomiting, ep & $49(25 \%)$ \\
\hline Diarr & loea (brief period) & 3 \\
\hline Dizzir & ess, vertigo, lassitude, headache & $27(13 \%)$ \\
\hline Skinr & & 6 \\
\hline Flush & swelling face & 1 \\
\hline ENL & 1st year only 27 & \\
\hline & 2 years & \\
\hline & 3 years & \\
\hline & 4 years & \\
\hline & Throughout 19 & 70 \\
\hline Rever & al reactions neuritis & 27 \\
\hline
\end{tabular}


Table 4. Cause of death.

\begin{tabular}{|c|c|c|c|c|}
\hline Classification & Age & $\begin{array}{c}\text { Duration of } \\
\text { disease (years) }\end{array}$ & Cause of death & $\begin{array}{c}\text { Years af ter } \\
\text { termination of treatment }\end{array}$ \\
\hline $\mathrm{L}$ & 52 & $>2$ & Renal failure & 0 \\
\hline $\mathrm{L}$ & 68 & 2 & Myocardial infarct & 0 \\
\hline $\mathrm{L}$ & 72 & $>32$ & Peritonitis & 4 \\
\hline $\mathrm{L}$ & 46 & $>21$ & Carcinoma mouth & 0 \\
\hline $\mathrm{L}$ & 69 & $>16$ & Hepatic failure (cirrhosis?) & 2 \\
\hline $\mathrm{L}$ & 70 & $>6$ & Heart failure & 0 \\
\hline $\mathrm{L}$ & 71 & 47 & Carcinoma stomach & 4 \\
\hline $\mathrm{L}$ & 42 & 27 & Heart failure & 0 \\
\hline $\mathrm{L}$ & 41 & $>12$ & Carcinoma mammae & 2 \\
\hline $\mathrm{L}$ & 76 & 31 & Carcinoma mammae & 0 \\
\hline $\mathrm{L}$ & 69 & $>9$ & Carcinoma lung & 0 \\
\hline $\mathrm{L}$ & 73 & $>11$ & Unknown & 5 \\
\hline $\mathrm{L}$ & 71 & $>12$ & Unknown & 4 \\
\hline $\mathrm{L}$ & 66 & $>30$ & Unknown & 2 \\
\hline $\mathrm{L}$ & 38 & $>9$ & Unknown & 2 \\
\hline $\mathrm{L}$ & 50 & 33 & Unknown & 2 \\
\hline $\mathrm{L}$ & 70 & 33 & Unknown & 1 \\
\hline $\mathrm{L}$ & 52 & $>8$ & Unknown & 2 \\
\hline $\mathrm{L}$ & 84 & $>16$ & Unknown & 3 \\
\hline BL & 61 & $>14$ & Cardio-renal insufficiency & 2 \\
\hline BT & 76 & 25 & Carcinoma mammae & 4 \\
\hline $\mathrm{T}$ & 76 & 34 & Myocarditis & 3 \\
\hline $\mathrm{T}$ & 51 & $>18$ & Carcinoma lung & 5 \\
\hline
\end{tabular}

patients, who were found bacteriologically positive in biopsies was a positive morphological index found.

Only one patient with active lepromatous leprosy had shown no bacteriological improvement af ter MDT, but in this patient the treatment had been very brief and the patient was noncompliant. One nonlepromatous patient showed at the time of the assessment reactivation of pre-existing lesions. This reactive phenomenon was diagnosed as a late reversal reaction.

\section{Conclusion}

In a series of patients in Malaysia who had become bacteriologically negative after sulphone monotherapy, about $1 \%$ relapse per annum was seen during a follow-up period of 10 years and relapses occurred already in the first four years after cessation of chemotherapy (Waters, personal communication). 
In Malta a high proportion of the patients were still bacteriologically positive when chemotherapy was withdrawn.

It is concluded that the patient material in Malta is suitable for comparing the results of treatment with rifampicin-Isoprodian with monotherapy with sulphones. The results in Malta, after a follow-up period of 4 years after cessation of treatment are, in view of the absence of relapses, superior.

In Malta no evidence of serious toxicity of the drug combination was found, but less serious side-effects were common.

\section{Acknowledgments}

The author wishes to thank Dr E Bonnici and Dr G Depasquale, who are executing the programme in Malta, for their kind and valuable cooperation, Professor Dr E Freerksen for making available all previous bacteriological data and the Ministry of Health of the Government of Malta for permission to publish the findings. 